\title{
Analisis Good Corporate Governance Terhadap Manajemen Laba pada Perusahaan Manufaktur yang Terdaftar di Bursa Efek Indonesia
}

\author{
Joyce Lim, Dian Lestari Siregar \\ Universitas Putera Batam, Indonesia \\ Universitas Putera Batam, Indonesia \\ Email: pb170810227@upbatam.ac.id
}

\begin{abstract}
The inequality in obtaining information that occurs between the principal and the agent is known as information asymmetry, which provides an opportunity for managers to perform earnings management. Earnings management is done by manipulating various information contained in the financial statements of a company. Good Corporate Governance (GCG) is a solution to minimize earnings management so that the company's condition is healthier, which of course uses certain principles. This study aims to examine the effect of the GCG mechanism on earnings management. The GCG mechanism used in this study consists of independent commissioners, institutional ownership, managerial ownership, and an audit committee. The research population is manufacturing companies in the consumer goods industry sector listed on the Indonesia Stock Exchange (IDX) for the 2015-2019 period using purposive sampling method. The results showed that partially or from each of the GCG mechanisms used by the study, independent commissioners had no effect on earnings management, managerial ownership had no effect on earnings management, institutional ownership had no effect on earnings management, and the audit committee had a significant effect on management. profit. However, simultaneously, independent commissioners, managerial ownership, institutional ownership, and the audit committee have a significant effect on earnings management.
\end{abstract}

Keywords: Earnings Management, Good Corporate Governance

\section{Pendahuluan}

Perusahaan memiliki tujuan pendirian untuk mencari keuntungan atau laba yang sebesar-besarnya dan mempertahankan keberlangsungan hidup perusahaan dimasa mendatang. Perusahaan harus dapat mengelola dan memanfaatkan sumber daya yang disediakan dengan efektif dan efisien. Pengelolaan dan pemanfaatan sumber daya dalam rangka memperoleh laba dapat dilihat melalui informasi yang telah tersaji dalam bentuk laporan yang disebut sebagai laporan keuangan.

Suatu laporan keuangan wajib memberikan informasi yang relevan (relevance), dapat dipahami (understandabillity), keandalan (reliability), dan dapat dibandingkan. Laporan keuangan memuat informasi laba yang tidak hanya penting bagi pihak dalam perusahaan, tetapi juga bagi pihak diluar perusahaan. Kebanyakan pihak eksternal perusahaan hanya memfokuskan pada angka laba yang terdapat pada laporan keuangan tanpa mengetahui atau mempertimbangkan cara memperoleh laba tersebut. Hal ini memicu terjadinya asimetri informasi, suatu kondisi pada pihak satunya memiliki informasi yang dibanding dengan pihak lain.

Asimetri informasi dapat mendorong manajer perusahaan untuk melakukan hal yang menyimpang seperti memanipulasi laba atau manajemen laba (earnings management). Manajemen laba atau manipulasi informasi akuntansi khususnya laba (earnings) dilakukan manajer atau pembuat laporan keuangan demi kepentingan pribadi dan perusahaan. Ketidakseimbangan dalam penyampaian informasi dapat memicu konflik kepentingan yang terjadi pada agen dan principal (Rahmawati et al., 2017). Manajer sebagai perwakilan pihak internal perusahaan, cenderung mudah dalam mendapatkan informasi mengenai perusahaan dan menjadi suatu peluang baginya untuk melakukan manajemen laba.

Tindakan manajemen laba pernah kejadian pada Indonesia di Perusahaan Listrik Negara (PLN). Diketahui bahwa laba bersih periode 2018 Rp11,56 triliun dan pada periode 2017 Rp4,42 triliun. Peningkatan laba sebesar 162,30\% dianggap tidak begitu wajar. Kuartal III periode 2019, perusahaan mengalami kerugian selisih kurs sebesar Rp17,32 triliun sehingga total kerugiannya adalah Rp18,48 triliun. Setelah diselidiki, perbedaan nilai tersebut terjadi karena perusahaan mencatat piutang sebagai pendapatan perusahaan. Pendapatan diperiode 2017 adalah Rp255,29 triliun dan meningkat diperiode 2018 menjadi Rp272,89 triliun. Beban usaha periode 2017 Rp275,47 triliun dan di 2018 Rp308,18 triliun. Pendapatan PLN tidak sebanding dengan beban usaha yang dimiliki. Periode 2017 perusahaan mengalami kerugian selisih kurs bernilai Rp2,93 triliun dan periode 2018 Rp10,92, berarti rugi selisih 
kurs PLN meningkat sebesar 272,27 \% (sumber: CNN Indonesia, "Menyoal Laba BUMN yang Mendadak Kinclong").

Manajemen laba bisa diatasi dengan penerapan Good Corporate Governance (GCG) yang diperkenalkan oleh Cadbury Committee tahun 1992 pertama kali dilaporannya "Cadbury Report. Menurut Watts dan Zimmerman pada tahun 1990, GCG diterapkan oleh perusahaan dengan harapan agar praktik manajemen laba dapat berkurang (Widianjani \& Yasa, 2020).Tata kelola perusahaan melibatkan masalah responsibilitas, yang mengutamakan perwujudan aturan dan mekanisme guna memverifikasi perilaku baik serta memenuhi kepentingan investor. Tata pengelolaan perusahaan yang baik merupakan cerminan manajemen perusahaan yang sehat dan transparan, diharapkan mencegah manajemen laba perusahaan.

Oleh sebab itu, peneliti peneliti ingin mengetahui penerapan GCG suatu entitas, terutama Komite Audit, Kepemilikan Institusional, Komisaris Independen, dan Kepemilikan Manajerial memiliki pengaruh pada manajemen laba secara masing-masing mekanisme (parsial) dan keseluruhan mekanisme (simultan) pada perusahaan-perusahaan manufaktur yang telah mendaftarkan diri di Bursa Efek Indonesia.

\section{Metodologi Penelitian}

\subsection{Desain Penelitian}

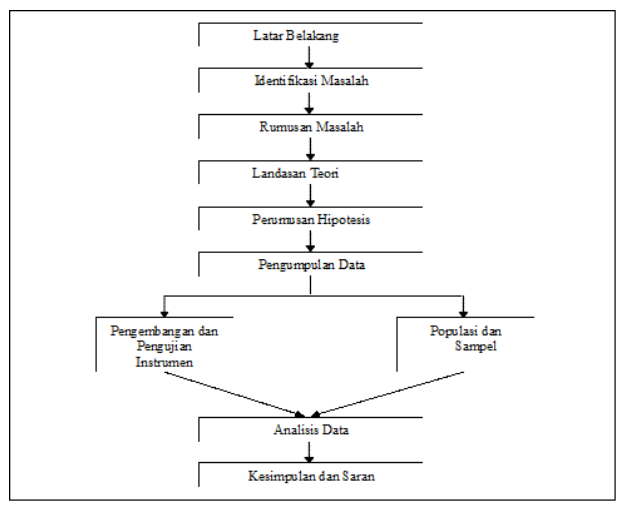

Penggunaan metode kuantitatif dalam penelitian ini yang juga sering disebut sebagai metode tradisional, positivistic, scientific, dan metode discovery. Penelitian merupakan penelitian eksplanatori (explanatory research) dan ditujukan untuk mengetahui pengaruh kepemilikan institusional, komite audit, kepemilikan manajerial, dan komisaris independen terhadap manajemen laba.

\subsection{Populasi dan Sampel}

Penelitian dilakukan pada perusahaan manufaktur mendaftarkan dirinya ke Bursa Efek Indonesia, khususnya sektor industri barang konsumsi. Sampel ditentukan melalui purposive sampling, sehingga diperoleh sampel sebanyak 11 perusahaan dari 58 perusahaan yang merupakan populasi penelitian. Peneliti menetapkan kriteria-kriteria sampel sebagai berikut:

1. Perusahaan manufaktur yang telah dicatat dalam Bursa Efek Indonesia khususnya bidang industri barang konsumsi (consumer goods industry).

2. Perusahaan telah mempublikasikan laporan keuangannya selama periode 2015-2019 dan telah diaudit.

3. Informasi terkait data-data yang berhubungan kepemilikan manajerial, komite audit, kepemilikan institusional, dan komisaris independen yang digunakan sebagai variabel untuk meneliti tersedia lengkap.

\subsection{Variabel Penelitian}

Perhitungan mekanisme GCG yang digunakan sebagai variabel independen pada penelitian ini sebagai berikut:। 
1. Komisaris Independen (X1), dihitung dengan rumus:

2. Kepemilikan Manajerial (X2), menggunakan rumus:

$$
\text { Kom. Independen }=\frac{\text { Jlh Kom. Independen }}{\text { Total Dewan Komisaris }}
$$

$$
\text { Kep. } \text { Manajerial }=\frac{\text { Saham milik Manajemen }}{\text { Total Saham Beredar }}
$$

3. Kepemilikan Institusional (X3), rumus yang digunakan yaitu:

$$
\text { Kep. Institusional }=\frac{\text { Saham milik Institusi }}{\text { Total Saham Beredar }}
$$

4. Komite Audit (X4), perhitungan dilakukan dengan berdasarkan jumlah komite audit pada perusahaan.

Variabel dependen (Y) penelitian ini adalah Manajemen Laba yang dihitung dengan menggunakan Proxy discretionary accrual yang merupakan proksi dengan model Jones yang telah dimodifikasi oleh Dechow bersama dengan rekannya Sloan dan Sweeney (1995). Proksi ini dihitung menggunakan pendekatan cash flow sebagai penentuan total accruals sampel. Perhitungan manajemen laba dirumuskan sebagai berikut:

$$
\mathrm{TA}_{\mathrm{it}} / \mathrm{A}_{\mathrm{it}-1}=\left(\mathrm{NI}_{\mathrm{t}}-\mathrm{OCF}_{\mathrm{t}}\right) / \mathrm{A}_{\mathrm{it}-1}
$$

Keterangan:

$\mathrm{TA}_{\mathrm{it}}$ : Total Accruals perusahaan pada periode ke $\mathrm{t}$

$\mathrm{A}_{\mathrm{it}-1}$ : Total Asset untuk sampel perusahaan pada periode ke t-1

$\mathrm{NI}_{\mathrm{t}}$ : Laba bersih operasi (net operating incomes) perusahaan pada periode ke $\mathrm{t}$

$\mathrm{OCF}_{\mathrm{t}}$ : Aliran kas dari aktivitas operasi (operating cash flow) perusahaan pada periode ke $\mathrm{t}$

\subsection{Teknik Pengumpulan Data}

Penelitian menggunakan data sekunder, yaitu data yang telah ada disediakan oleh orang-orang yang yang mempublikasikan data tersebut. Data yang diperlukan berupa laporan keuangan tahunan dengan penyajian informasi yang lengkap terkait komisaris independen, kepemilikan manajerial, komite audit, kepemilikan institusional, dan indikator-indikator yang diperlukan untuk manajemen laba.

\section{Hasil Dan Pembahasan}

\subsection{Hasil Penelitian}

\subsubsection{Uji Statistik Deskriptif}

Uji statistik deskriptif disajikan tabel yang berisikan nilai minimum, maksimum, mean, dan deviasi standar dari masing-masing variabel yang menjadi objek observasi.

Tabel 1. Uji Statistik Deskriptif

Descriptive Statistics

\begin{tabular}{lrrrrr}
\hline & N & Minimum & Maximum & \multicolumn{1}{c}{ Mean } & Std. Deviation \\
\hline X1_Kom.Idpd & 55 & .33 & 2.67 & .4352 & .31711 \\
X2_Kep.Mnjr & 55 & .00006 & .68276 & .0977981 & .18494169 \\
X3_Kep.Inst & 55 & .01225 & .97784 & .4038437 & .30459851 \\
X4_Kom.Audit & 55 & 3 & 4 & 3.02 & .135 \\
Y_Mnjmn.Laba & 55 & -.13128 & .20547 & -.0121279 & .05959541 \\
Valid N (listwise) & 55 & & & & \\
\hline
\end{tabular}

(Sumber: Hasil Uji SPSS 24)

\subsubsection{Uji Asumsi Klasik}

\subsubsection{Uji Normalitas}

Uji normalitas pada penelitian ini terdiri dari Histogram, Normal P-P Plot, dan One Sample K-S. (Banjarnahor \& Lubis, 2020) Jika grafik histogram tidak terlalu ke kiri ataupun ke kanan, maka data dapat dikatakan sudah normal. Uji normalitas dengan Normal P-P Plot, data ditandai dengan bentuk titik-titik. Jika data tersebar pada sekitar garis diagonal, maka data tersebut dianggap normal dan dapat 
melanjutkan penelitian. Uji One Sample $K$-S, jika nilai signifikan $\mathrm{p}<0,05$ berarti ditemukan perbedaan yang signifikan atau data tidak normal, dan sebaliknya, jika nilai signifikan $p>0,05$ maka tidak ada perbedaan yang signifikan. Hasil uji dnegan nilai signifikan 0,200 >0,05 yang berarti tidak ditemukan perbedaan yang signifikan sehingga penelitian dapat berlanjut.

Tabel 2. Uji Normalitas - One Sample K-S

One-Sample Kolmogorov-Smirnov Test

\begin{tabular}{|c|c|c|}
\hline & & $\begin{array}{l}\text { Unstandardized } \\
\text { Residual }\end{array}$ \\
\hline $\mathrm{N}$ & & 55 \\
\hline \multirow[t]{2}{*}{ Normal Parameters ${ }^{\mathrm{a}, \mathrm{b}}$} & Mean & .0000000 \\
\hline & Std. Deviation & .04935381 \\
\hline \multirow[t]{3}{*}{ Most Extreme Differences } & Absolute & .063 \\
\hline & Positive & .063 \\
\hline & Negative & -.045 \\
\hline Test Statistic & & .063 \\
\hline Asymp. Sig. (2-tailed) & & $.200^{\mathrm{c}, \mathrm{d}}$ \\
\hline
\end{tabular}

a. Test distribution is Normal.

b. Calculated from data.

c. Lilliefors Significance Correction.

$\mathrm{d}$. This is a lower bound of the true significance.

(Sumber: Hasil Uji SPSS 24)

3.1.2.2 Uji Multikolinearitas

Tabel 3. Uji Multikolinearitas

Coefficients $^{\mathrm{a}}$

\begin{tabular}{llrr}
\hline & & \multicolumn{2}{c}{ Collinearity Statistics } \\
& & Tolerance & VIF \\
\hline 1 X1_Kom.Idpd & .991 & 1.009 \\
& X2_Kep.Mnjr & .904 & 1.106 \\
X3_Kep.Inst & .879 & 1.137 \\
X4_Kom.Audit & .953 & 1.050 \\
\hline
\end{tabular}

a. Dependent Variable: Y_Mnjmn.Laba

(Sumber: Hasil Uji SPSS 24)

Uji yang dilakukan untuk mengontrol bias pada variabel independen yang memiliki jumlah lebih dari 1 dan setiap dari variabel tersebut tidak memiliki hubungan, variabel-variabel tersebut tidak saling mempengaruhi antar variabel independen. Jika pada nilai VIF $<10$ dan Tolerance $>0,1$, maka data yang digunakan normal.

\subsubsection{Uji Heteroskedastisitas}

Tabel 4. Uji Heterokedastisitas - Uji Glejser

Coefficients $^{\mathbf{a}}$

\begin{tabular}{llrrrrr}
\hline \multicolumn{1}{c}{ Model } & \multicolumn{2}{c}{$\begin{array}{c}\text { Unstandardized } \\
\text { Coefficients }\end{array}$} & $\begin{array}{c}\text { Standardized } \\
\text { Coefficients } \\
\text { Beta }\end{array}$ & \multicolumn{1}{c}{ t } & Sig. \\
& B & \multicolumn{1}{c}{ Std. Error } & \multicolumn{1}{c}{ Betar } & \\
\hline 1 (Constant) & .178 & .093 & & 1.922 & .060 \\
& X1_Kom.Idpd & -.019 & .013 & -.198 & -1.513 & .136 \\
X2_Kep.Mnjr & .027 & .023 & .164 & 1.200 & .236 \\
X3_Kep.Inst & -.018 & .014 & -.176 & -1.270 & .210 \\
& X4_Kom.Audi & -.042 & .030 & -.186 & -1.396 & .169 \\
t & & & & & \\
\hline
\end{tabular}

a. Dependent Variable: ABRESID

(Sumber: Hasil Uji SPSS 24) 
Uji heteroskedastisitas yang digunakan yaitu uji scatter-plot dan uji glejser. Hasil uji glejser menunjukkan nilai signifikan konstan $0,060>0,05$ maka pada penelitian ini tidak terdapat heteroskedastisitas dan penelitian dapat dilanjutkan. Pada uji scatter-plot, titik plot data yang tersaji pada grafik jika menyebar dan jauh dari titik 0 membentuk pola garis lurus dari kiri bawah ke kanan atas, maka variabel independen dan variabel dependen tersebut memiliki hubungan yang linear dan positif.

\subsubsection{Uji Auto Korelasi}

Uji yang digunakan penelitian adalah Uji Durbin-Watson. Hasil penelitian menunjukkan nilai DW 2,245, maka $2.245>1,7240$ dan $(4-2,245)>1,7240$ atau 1,755 > 1,7240. Hal ini menunjukkan tidak terjadinya autokorelasi data penelitian dan penelitian dapat berlanjut.

Tabel 5. Uji Autokorelasi

Model Summary ${ }^{\mathrm{b}}$

\begin{tabular}{lrrrrr}
\hline Model & \multicolumn{1}{l}{ R } & R Square & $\begin{array}{c}\text { Adjusted R } \\
\text { Square }\end{array}$ & $\begin{array}{c}\text { Std. Error of the } \\
\text { Estimate }\end{array}$ & Durbin-Watson \\
\hline 1 & $.561^{\mathrm{a}}$ & .314 & .259 & .05128998 & 2.245 \\
\hline
\end{tabular}

a. Predictors: (Constant), X4_Kom.Audit, X1_Kom.Idpd, X2_Kep.Mnjr,

X3_Kep.Inst

b. Dependent Variable: Y_Mnjmn.Laba

(Sumber: Hasil Uji SPSS 24)

\subsubsection{Uji Regresi Linear Berganda}

Uji regresi linear berganda bertujuan menguji pengaruh antara variabel satu dengan variabel lain yang dinyatakan dalam suatu persamaan regresi. Uji ini menggunakan persamaan berikut: $\mathrm{Y}^{\prime}=\mathrm{a}+\mathrm{b} 1 \mathrm{X} 1+\mathrm{b} 2 \mathrm{X} 2+\mathrm{b} 3 \mathrm{X} 3+\mathrm{b} 4 \mathrm{X} 4$ sehingga persamaan regresi linear berganda pada penelitian ini berdasarkan hasil uji yang dilakukan adalah $Y^{\prime}=-0,660+0,003-0,077+0,006+0,216$.

Tabel 6. Uji Regresi Linear Berganda

\begin{tabular}{|c|c|c|c|c|c|c|}
\hline \multicolumn{7}{|c|}{ Coefficients $^{\mathrm{a}}$} \\
\hline & \multirow{2}{*}{ Model } & \multicolumn{2}{|c|}{ Unstandardized Coefficients } & \multirow{2}{*}{$\begin{array}{c}\text { Standardized } \\
\text { Coefficients } \\
\text { Beta } \\
\end{array}$} & \multirow{2}{*}{$\mathrm{t}$} & \multirow{2}{*}{ Sig. } \\
\hline & & B & Std. Error & & & \\
\hline \multirow[t]{5}{*}{1} & (Constant) & -.660 & .163 & & -4.051 & .000 \\
\hline & X1_Kom.Idpd & .003 & .022 & .016 & .137 & .891 \\
\hline & X2_Kep.Mnjr & -.077 & .040 & -.239 & -1.943 & .058 \\
\hline & X3_Kep.Inst & .006 & .024 & .029 & .235 & .815 \\
\hline & X4_Kom.Audit & .216 & .053 & .489 & 4.075 & .000 \\
\hline
\end{tabular}

a. Dependent Variable: Y_Mnjmn.Laba

(Sumber: Hasil Uji SPSS 24)

\subsubsection{Uji Hipotesis}

\subsubsection{Uji t}

Uji t merupakan uji hipotesis atau pengujian pengaruh setiap variabel independen pada variabel dependen. Tabel hasil pengujian yang disajikan untuk uji $t$ adalah tabel yang sama dengan tabel hasil uji regresi linear berganda. Jika pada tabel masing-masing variabel independen bernilai signifikan $\mathrm{p}<$ 0,05 , maka model regresi yang diformulasikan sudah tepat.

\subsubsection{Uji F}

Uji $\mathrm{F}$ dilakukan untuk menguji pengaruh variabel independen pada variabel dependen dengan simultan (keseluruhan). Hasil uji ini disajikan dalam tabel anova, jika nilai signifikan tabel hasil uji menunjukkan $\mathrm{p}<0,05$, maka formulasi model regresi sudah tepat. Hasil uji data pada penelitian ini adalah sebesar $0,001<0,05$ dan nilai $F$ hitung 5,726 $>\mathrm{F}$ tabel 2,55 yang berarti variabel independen memiliki pengaruh signifikan secara simultan pada variabel dependen penelitian. 
Tabel 7. Uji Hipotesis - Uji F

\begin{tabular}{llrrrrr}
\multicolumn{7}{c}{ ANOVA $^{\mathbf{a}}$} \\
\hline & \multirow{2}{*}{ Model } & \multicolumn{1}{c}{$\begin{array}{c}\text { Sum of } \\
\text { Squares }\end{array}$} & df & Mean Square & F & Sig. \\
\hline $1 \quad$ Regression & .060 & 4 & .015 & 5.726 & $.001^{\text {b }}$ \\
& Residual & .132 & 50 & .003 & & \\
& Total & .192 & 54 & & & \\
\hline
\end{tabular}

a. Dependent Variable: Y_Mnjmn.Laba

b. Predictors: (Constant), X4_Kom.Audit, X1_Kom.Idpd, X2_Kep.Mnjr, X3_Kep.Inst

(Sumber: Hasil Uji SPSS 24)

\subsubsection{Uji Koefisien Determinasi (R2)}

Uji koefisien determinasi menunjukkan besaran variasi variabel independen yang dapat menjelaskan variasi variabel dependen. Untuk mengetahui persentase atau besaran koefisien determinasi dilihat dari nilai Adjusted R Square yang disajikan pada tabel hasil uji yaitu sebesar 0,259 atau $25,9 \%$.

Tabel 8. Uji Koefisien Determinasi (R2)

\begin{tabular}{lcrrrr}
\multicolumn{7}{c}{ Model Summary $^{\mathbf{b}}$} \\
\hline $\begin{array}{l}\text { Mo } \\
\text { del }\end{array}$ & \multirow{2}{*}{ R } & $\begin{array}{c}\text { R } \\
\text { Square }\end{array}$ & $\begin{array}{c}\text { Adjusted R } \\
\text { Square }\end{array}$ & $\begin{array}{c}\text { Std. Error of the } \\
\text { Estimate }\end{array}$ & $\begin{array}{l}\text { Durbin- } \\
\text { Watson }\end{array}$ \\
\hline 1 & $.561^{\text {a }}$ & .314 & .259 & .05128998 & 2.245 \\
\hline
\end{tabular}

a. Predictors: (Constant), X4_Kom.Audit, X1_Kom.Idpd, X2_Kep.Mnjr, X3_Kep.Inst

b. Dependent Variable: Y_Mnjmn.Laba

(Sumber: Hasil Uji SPSS 24)

\subsection{Pembahasan}

\subsubsection{Pengaruh Komisaris Independen terhadap Manajemen Laba}

Hasil uji t menunjukkan nilai t hitung $0,137<$ nilai $t$ tabel 2,009 dan nilai signifikan 0,891>0,05. Ini membuktikan bahwa komisaris independen tidak memiliki pengaruh terhadap manajemen laba, sehingga hipotesis pertama $(\mathrm{H} 1)$ yang menyatakan komisaris independen memiliki pengaruh terhadap manajemen laba, ditolak. Umumnya, komisaris independen suatu perusahaan dipilih oleh pemegang saham mayoritas dan komisaris tersebut berkemungkinan diganti apabila komisaris tersebut tidak sejalan dengan pemilik perusahaan. Persentase komisaris independen relatif besar tidaklah menandakan bahwa komisaris tersebut telah sepenuhnya bertindak independen. Hal ini disebabkan adanya keterbatasan dalam melakukan pengawasan oleh peraturan dan kebijakan yang berlaku yang ditetapkan oleh pemegang saham mayoritas, berdampak implementasi good corporate governance secara optimal untuk mengurangi kemungkinan manajemen laba pada suatu perusahaan menjadi sulit.

\subsubsection{Pengaruh Kepemilikan Manajerial terhadap Manajemen Laba}

Hasil uji t membuktikan kepemilikan manajerial dengan nilai $t$ hitung $-1,943<\mathrm{t}$ tabel 2,009 dan nilai signifikan 0,058 >0,05. Disimpulkan dari hasil uji bahwa kepemilikan manajerial tidak memberi pengaruh terhadap manajemen laba, sehingga menolak pernyataan hipotesis kedua (H2), bahwa kepemilikan manajerial memberi pengaruh pada manajemen laba. (Yogi \& Damayanthi, 2016) Persentase saham yang dimiliki oleh pihak manajemen perusahaan relatif kecil, sehingga manajer perusahaan cenderung berhati-hati dalam mengambil suatu keputusan atau menetapkan kebijakan dengan memperhatikan sudut pandang dari investor yang cenderung tertarik pada perolehan laba yang besar. 


\subsubsection{Pengaruh Kepemilikan Institusional terhadap Manajemen Laba}

Tabel uji $\mathrm{t}$ menunjukkan $\mathrm{t}$ hitung $0,235<\mathrm{t}$ tabel 2,009 dan nilai signifikan $0,815>0,05$. Hasil tersebut membuktikan bahwa kepemilikan institusional tidak memberi pengaruh pada manajemen laba dan hipotesis ketiga (H3) yang menyatakan kepemilikan institusional memberi pengaruh pada manajemen laba, ditolak. (Partayadnya \& Suardikha, 2018) Pada umumnya, investor institusional merupakan pemilik bersifat sementara (transient investors) dan berfokus pada laba saat ini (current earnings) dan tidak berperan sebagai sophisticated investors yang dapat memonitor dan mendisiplinkan manajer perusahaan agar dapat fokus meningkatkan nilai perusahaan.

\subsubsection{Pengaruh Komite Audit terhadap Manajemen Laba}

Variabel komite audit pada hasil uji t hitung 4,075 > t tabel 2,009 dan nilai signifikan 0,000 $<0,05$, menunjukkan bahwa komite audit memiliki pengaruh signifikan terhadap manajemen laba. Pernyataan hipotesis keempat (H4) bahwa komite audit berpengaruh terhadap manajemen laba, diterima. Komite audit perusahaan telah melaksanakan tanggung jawabnya dengan baik, sehingga integritas dari laporan audit tercapai dan kualitas laporan keuangan menjadi lebih baik dan mengurangi kasus manajemen laba pada perusahaan.

\subsubsection{Pengaruh Komisaris Independen, Kepemilikan Manajerial, Kepemilikan Institusional, Komite} Audit terhadap Manajemen Laba

Hasil penelitian uji $\mathrm{F}$ yang tersaji pada tabel anova memiliki nilai signifikan $0,001<0,05$ dan nilai F hitung 5,726 > F tabel 2,55. Keseluruhan variabel independen, komite audit, kepemilikan manajerial, kepemilikan institusional dan komisaris independen memiliki pengaruh terhadap manajemen laba dan pernyataan hipotesis kelima (H5) diterima, bahwa komite audit, kepemilikan manajerial, kepemilikan institusional dan komisaris independen berpengaruh terhadap manajemen laba secara simultan.

\section{Kesimpulan}

Kesimpulan

Berdasarkan hasil penelitian dan pembahasan, dapat ditarik kesimpulan bahwa:

1. Komisaris independen tidak memiliki pengaruh terhadap manajemen laba.

2. Kepemilikan manajerial tidak memiliki pengaruh terhadap manajemen laba.

3. Kepemilikan institusional tidak memiliki pengaruh pada manajemen laba.

4. Komite audit memiliki pengaruh signifikan terhadap manajemen laba.

4. Secara simultan (keseluruhan) komisaris independen, kepemilikan manajerial, kepemilikan institusional, dan komite audit berpengaruh signifikan terhadap manajemen laba.

\section{DAFTAR PUSTAKA}

Agustini, T., \& Siregar, D. L. (2020). Pengaruh Fee Audit, Audit Tenure dan Rotasi Audit Terhadap Kualitas Audit di Bursa Efek Indonesia. EMBA : Jurnal Riset Ekonomi, Manajemen, Bisnis Dan Akuntansi, 8 No. 1(ISSN 2303-1174), 637-648.

Banjarnahor, H., \& Lubis, S. H. (2020). Identification of Variables That Improve the Reveneus of Entertainment Tax in the City of Batam City with GRDP Price Apply as Moderating Variable. November, 1011-1019. https://doi.org/10.5220/0009500910111019

Banjarnahor, H., \& Yando, A. D. (2018). Mekanisme Good Corporate Governance Terhadap Manajemen Laba dengan Kinerja Keuangan Sebagai Variabel Moderasi. Jurnal Ilmiah Akuntansi Dan Finansial Indonesia, 2 No. 1, 29-40. https://doi.org/https://doi.org/10.31629/jiafi.v2i1.1275

Cahyadi, I. M. K., \& Mertha, I. M. (2019). Pengaruh Good Corporate Governance dan Ukuran Perusahaan pada Manajemen Laba. E-Jurnal Akuntansi Universitas Udayana, 27.1(ISSN : 2302-8556), 173-200.

Chairunesia, W., Sutra, P. R., \& Wahyudi, S. M. (2018). Pengaruh Good Corporate Governance dan Financial Distress Terhadap Manajemen Laba pada Perusahaan Indonesia yang Masuk Dalam ASEAN Corporate Governance Scorecard. Profita: Komunikasi Ilmiah Akuntansi Dan Perpajakan, 11 No. 2(p-ISSN : 20867662 e-ISSN : 2622-1950), 232-249. 
Giovani, M. (2017). Pengaruh Struktur Kepemilikan, Tata Kelola Perusahaan, dan Karakteristik Perusahaan Terhadap Manajemen Laba. Jurnal Akuntansi Bisnis, 15 No. 2(e-ISSN :2541-5204), 290-304.

Hamdani, M. (2016). Good Corporate Governance (GCG) dalam Perspektif Agency Theory. SEMNAS FEKON, 279-283.

Hidayat, M. (2016). Pengaruh Good Corporate Governance dan Ukuran Perusahaan Terhadap Manajemen Laba. JOM FEKON, 3 No. 1, 234-248.

Janrosl, V. S. E., \& Lim, J. (2019). Analisis Pengaruh Good Corporate Governance terhadap Manajemen Laba pada Perusahaan Perbankan yang terdaftar di BEI. Owner : Riset \& Jurnal Akuntansi, 3 No. 2(e-ISSN : 25489224 p-ISSN: 2548-7507), 226-238.

Partayadnya, I. M. A., \& Suardikha, I. M. S. (2018a). Pengaruh Mekanisme GCG, Kualitas Audit, dan Leverage Terhadap Manajemen Laba pada Perusahaan Manufaktur di BEI. E-Jurnal Akuntansi Universitas Udayana, 25(2302-8226), 31-53.

Partayadnya, I. M. A., \& Suardikha, I. M. S. (2018b). Pengaruh Mekanisme GCG, Kualitas Audit, dan Leverage Terhadap Manajemen Laba pada Perusahaan Manufaktur di BEI. E-Jurnal Akuntansi Universitas Udayana, 25 No. 1(ISSN : 2302-8556), 31-53.

Rahmawati, M., Khikmah, S. N., \& Dewi, V. S. (2017). Pengaruh Kualitas Auditor dan Corporate Governance Terhadap Manajemen Laba. URECOL, ISSN : 2407-9189.

Rianto, A., \& Herawaty, V. (2019). Peran Diversifikasi Sebagai Pemoderasi Pengaruh Profitabilitas, Ukuran Perusahaan, dan GCG Terhadap Manajemen Laba Riil. Seminar Nasional Cendekiawan Ke 5, ISSN (P) : 2460-8696 ISSN (E) : 2540-7589.

Sugiyono. (2012). Metode Penelitian Kuantitatif Kualitatif dan R\&D. ALFABETA.

Teori Agensi Menurut Para Ahli Dalam Praktek Akuntansi. (2020). https://artikelpendidikan.id/teori-agensi/

Wahyuni, A. S. (2018). Kritik Teori Keagenan Dalam Artikel Akuntansi : Konteks Ke-Indonesia-an. JATI : Jurnal Akuntansi Dan Teknologi Informasi, 12 No. 2.

Widianjani, N. P., \& Yasa, G. W. (2020). Pengaruh Good Corporate Governance Terhadap Manajemen Laba Oleh CEO Baru pada Perusahaan Manufaktur. E-Jurnal Akuntansi, 30 No. 1(e-ISSN : 2302-8556), $251-264$.

Widyaningsih, D. (2018). Kepemilikan Manajerial, Kepemilikan Institusional, Komisaris Independen, Serta Komite Audit pada Nilai Perusahaan dengan Pengungkapan CSR sebagai Variabel Moderating dan Firm Size sebagai Variabel Control. JAP : Jurnal Akuntansi Dan Pajak, 19 No. 01(e-ISSN : 2579-3055), 38-52.

Widyaningsih, H. (2017). Pengaruh Corporate Governance Terhadap Manajemen Laba. Jurnal Nominal, VI No. 2, 91-107.

Yogi, L. M. D. P., \& Damayanthi, I. G. A. E. (2016). Pengaruh Arus Kas Bebas, Capital Adequacy Ratio, dam Good Corporate Governance pada Manajemen Laba. E-Jurnal Akuntansi Universitas Udayana, 15 No. 2(ISSN : 2302-8556), 1056-1085. 